\title{
Making the provincial relevant? Embracing the provincialization of continental European geographies
}

\author{
Myriam Houssay-Holzschuch \\ Univ. Grenoble Alpes, CNRS, Sciences Po Grenoble, Pacte, 38100 Grenoble, France \\ Correspondence: Myriam Houssay-Holzschuch (myriam.houssay@normalesup.org)
}

Received: 18 June 2019 - Revised: 16 March 2020 - Accepted: 27 March 2020 - Published: 24 April 2020

\begin{abstract}
English-speaking hegemony shapes the geography of legitimate knowledge production in our discipline, pushing geographies in other languages and traditions to the periphery. The overall phenomenon has overshadowed these peripheries' diversity and what is at stake within them. I argue that continental European geographies occupy a specific position - they have been provincialized rather than peripheralized. This provincialization should not be lamented. Given our colonial past and Northern privilege, we should instead embrace this provincialization as long overdue and a moral imperative. I subsequently explore a few provincializationembracing postures - all with merit, none unproblematic - that we can adopt for fieldwork and writing. I then propose practical steps that continental European geographies can take toward a more ethical and cosmopolitan praxis.
\end{abstract}

Jacques Paganel, pendant ses trois jours de captivité chez les Maoris, avait été tatoué, mais tatoué des pieds aux épaules, et il portait sur sa poitrine l'image d'un kiwi héraldique, aux ailes éployées, qui lui mordait le cœur. (Jules Verne, Les Enfants du Capitaine Grant)

\section{Introduction}

What is the way forward for continental European geographies ${ }^{1}$ ?

Since the end of the 20th century, continental European geographies have found themselves becoming peripheral to Anglophone geographies and, more generally, to the Anglosphere. Our institutions are increasingly reluctant to recognize publications in our languages, and such publications severely confine our readership. The concepts with which we continental geographers work have a very limited export capacity by not translating well into English or the continent's

\footnotetext{
${ }^{1}$ The United Kingdom has a specific position by being European, a former colonial power and a member of the Anglo hegemony, meaning that the kind of work required in the UK differs from that required from continental European geographers, which is the focus of my article.
}

other languages. Actually, we do not even read each other's writing much unless we truly work on the same topic.

In addition, we also have a very specific positionality within this global reconfiguration of the geographies of knowledge production because while we are becoming peripheral, we, as part of the Western world, retain many privileges. We often also have a past as colonial metropolises, which has allowed some of our languages to become and remain international ones. Whiteness and/or coloniality issues deeply infuse our societies and our discipline.

This article suggests that, while the current Anglo hegemony should not be justified, continental European geographies need to situate their current peripheralization within their historical trajectories and remember that, in their case, provincialization might be a politically, epistemologically and ethically positive project. We continental geographers should not lament our provincialization in the global geographical world as a recent demise but maybe embrace it, as a worthy, if challenging, political project for the discipline and our scholarly practices. As such, this article also contributes to the 2013 initiated Geographica Helvetica editorial project (Korf et al., 2013) "to become a platform for the development of a creative, truly cosmopolitan geography" and to "provide an intellectual space of exchange and encounter 
for cosmopolitan European geographies to emerge". My objective here is thus to open up a conversation within these geographies, on the ethical and political dimensions of their (diverse) provincializations. Other discussions on our provincializations are certainly to be had: there are epistemological, theoretical, empirical and institutional arguments to be made and from positions that are different from mine, but these arguments go beyond the scope of this particular piece. I can only hope that the conversation will continue.

I write this piece from a specific positionality, as a midcareer, tenured, female, white, French geographer embedded in a national geographical tradition, but I believe that the topic should be part of a "cross-border" (Korf et al., 2013) debate between continental geographers. My positionality nevertheless shapes this analysis in many ways, the most relevant of which being linguistic and institutional. The French context is one in which the social sciences have kept on publishing in the national language: the pressure to publish in English is recent (a decade or so in human geography) and part of the contradictory institutional injunctions we have to deal with, as the neoliberalization of our public universities progresses under the pretense of "international excellence". At the same time, national and disciplinary debates still value publishing in French, not only because they see multilingualism as a good thing per se but also to desperately cling to our (linguistically much more dominant) past. Most universities are public, considered a public service, and faculty members are still state servants with early tenure ${ }^{2}$ : this institutional context makes older scholars less vulnerable to these injunctions to publish in English, while younger researchers in search of rapidly disappearing permanent positions bear the brunt of these new imperatives as recruitment committees' expectations now include "international" publications. But while this paper reflects my positionality, I try to open up perspectives on how questions around provincialization are differently deployed across continental Europe.

\section{A provincial condition}

\subsection{Marginality}

Since the 1990s, a large body of work (see for instance Garcia-Ramon, 2003; Aalbers and Rossi, 2007; Minca, 2000) has documented the geographies of knowledge pro-

\footnotetext{
${ }^{2}$ This is not to say that there is no casualization of labor at French university, alas, but that casualization takes on a differently brutal form. The teaching and researching precariat is mostly constituted of PhD students and some postdocs, and existing labor contracts tend to exclude long-term adjunctification by a limit in both duration and number of possible contracts. For instance, one can only be an ATER (Attaché Temporaire d'Enseignement et de Recherche, a precarious full-time research and teaching position) a maximum of 4 years. However, the Macron government is currently trying to change this through the hotly contested 2020 draft bill for research (Loi de programmation pluriannuelle de la recherche).
}

duction and, aside from Anglo hegemony, noted the increasing marginalization of other geographies published in other languages. Although Spanish-, German- and Frenchspeaking geographies had a prominent, if not dominant, status in the 19th century and in the first half of the 20th century, they have been fading into the background of legitimate geographies since that time. The current neoliberalization of academia and the obsession with rankings have intensified these processes, with journal articles becoming the standard mode of scientific writing and English-speaking journals the epitome of so-called scientific excellence. This is, however, deployed differently across continental Europe: while for example France has been keeping a vibrant landscape of academic journals in French (many of them open access), "journals of national associations have been publishing more and more in English or even English only (without necessarily changing their name: Tijdschrift voor Economische en Sociale Geografie in the Netherlands, Fennia in Finland, Erdkunde: Archiv für wissenschaftliche Geographie in Germany)" (Mamadouh, 2018).

The use of a lingua franca in scientific debates is nothing new, as both Latin and French adopted this role during particular periods in European history. But this history also teaches us that the reason for a particular language becoming a lingua franca is a reflection of both power relationships and a specific geopolitical configuration. This also applies to the current situation. The work of Graham et al. (2011) clarifies that indexed journals are not only published in English but are also produced in either the United States or in the UK. These two countries "publish more indexed journals than the rest of the world combined." More indexed US and UK journals are not only more numerous than any other country's indexed journals but also have a disproportionately high impact factor.

The role of a lingua franca is to facilitate the global dissemination of research results, to engage in international debates and to work towards a global conversation. English is therefore characterized as the language of minimal exclusion (Van Parijs, 2004) and as the most prestigious. More problematically, publishing in English is becoming a requirement for finding an academic job (especially in the current context of diminishing job openings and increased precariat) and for promotion purposes. Scholars in non-English-speaking countries are thus pressurized to publish in English (Curry and Lillis, 2013, 2017). Of course, they are differently vulnerable to such pressure: tenured faculty is less vulnerable than precarious researchers, and scholars at public universities will have to conform to diverse national systems of evaluation that value publications in English and in the national language very differently (some highly, some not at all). Nevertheless, the use of English is becoming hegemonic in the sense of Antonio Gramsci, as it combines consent (allowing for international discussions and bringing academic prestige) and coercion (becoming an institutional requirement on which geographers' careers increasingly depends). 
This hegemonic situation has drawn important critiques, and its far-ranging consequences have been explored by a trove of literature (Garcia-Ramon, 2003; or, for a very recent take, Imhof and Müller, 2020), for instance in how it impoverishes theoretical and epistemological perspectives, by subsuming them to what is expected by so-called international (a.k.a. US and UK) journals. These journals push towards theory - and very specific strands of theory at that, whose legitimation circles lie in the Anglosphere - and tend to assign less value to case studies ${ }^{3}$. Furthermore, and crucially for this paper, the scholarly hegemony of the Anglosphere (and publishing industry) reconfigures the provincialized scholars' relationship to the local. Peripheral cases are to be "made relevant" and sexy for publication. Writing for undergraduates or disseminating research towards secondary education colleagues does not pay - sometimes very literally - in career terms as it is not done in English. Outreach to local communities and institutions requires more work, as it now has to take place in another language than that of academic publication.

All these critiques are absolutely crucial, but their analyses tend to work dichotomously (Anglo vs. non-Anglo geographies), overshadowing what is at stake within peripheral geographies. These peripheral geographies are extremely diverse regarding their languages, national or international character and traditions, theoretical references, publishing structures, and higher education systems, to mention just a few. Consequently, these geographies need a critical, situated and reflexive analysis and characterization of their current marginal status to move toward a research, epistemological and political agenda.

A corollary of this diversity is that the provincial geographer cuts a complex figure. Race, class, career stage and employment status, age, gender, sexuality, disability, and location complicate relationships of power. As I do not have the space here to tackle these questions in-depth, I will just insist on a couple of elements. While hard quantitative data are difficult to find (a problem in itself; see Isopahkala-Bouret et al., 2018), European geographies remain overwhelmingly white as structural barriers stand in the way of Europeans of color accessing higher education. Their underrepresentation is exacerbated in geography by our "discipline's welldocumented, persistent and overwhelming whiteness" (Noxolo, 2017). Class and employment status, together with age, are other deep-cutting lines: the intensity of the changes undergone by European higher education systems in the last decades has produced wide generational gaps in how geographers have been socialized into their discipline, in the theoretical frameworks they use, in the institutional environments they work in, and in publication expectations and/or multilingualism. Lastly, the provincial geographer's location plays a huge role, as some continental European geographies remain embedded in linguistic subsystems of power, neo-colonial or

\footnotetext{
${ }^{3} \mathrm{My}$ thanks to one of the reviewers for this particular point.
}

not (typically the French, German and Spanish ones), while others are former colonial powers without a linguistic policy (e.g., Denmark or the Netherlands), and others have been colonized or oppressed by neighboring powers (Ireland, Finland, eastern Europe) and have encountered the current hegemonic system from a long-standing peripheral position.

\subsection{Why has the status quo remained unchanged for so long? Insularity and splendid isolation}

In this section, I focus on the marginal situation of French and Francophone geographies - the geographies I was socialized into and am still a part of. Houssay-Holzschuch and Milhaud (2013) have labeled this kind of marginality as provincial. According to these scholars, provincialism comprises the following elements.

- The provincial condition constitutes a subsystem within international geographies: a "core", "peripheral" interfaces and neo-colonial dependents that "provided French geography with a welcome exposure to the other, although from a secure power position". This subsystem also constitutes the field of most research; for example, $32 \%$ of all PhDs submitted in France between 1990 and 1994 dealt with France and $44 \%$ with former French colonies (Knafou, 1997).

- Provincialism is constructed around theoretical idiosyncrasies (specific sets of interrelated concepts) and a particular configuration of interdisciplinary relations.

- Internal instances of legitimation (journals and a publishing system distinct from the international, Anglodominated one, its universities, and its research subjects) and the local nobility of a specific discipline sustain the provincial system.

A strong element of insularity therefore characterizes provincial subsystems, such as the French one, as they tend to function in relative isolation. Bajerski (2011) shows that $82 \%$ of the authors published in French journals and $67 \%$ of the references are French. His quantitative study shows a similar insularity with respect to German and Spanish geographies: "on average [for all three languages], around 90 per cent of authors and 85 per cent of citations come from the same language area as the journal", leading him to conclude that "French, German and Spanish geographical journals not only fail to reach to a significant extent outside their own country and language area, but also fail to reach significantly outside Europe" (Bajerski, 2011). This insularity, which is probably diminishing, might be especially strong within linguistic subsystems. By contrast, European geographies that have chosen to function and publish research mostly in English and within the Anglo publishing industry - e.g., in the Netherlands or in Sweden - to the detriment of their national language seem to be more open, although we lack a study similar to Bajerski's to measure their actual porosity to, respectively, authors 
and references beyond their national borders and the Anglosphere.

In the French case, provincialism and insularity are the results of the marginalization process that non-Anglo geographies have undergone and which applies to a national and linguistic tradition that used to be one of the most powerful in the world. Conversely, when applied to geographies that were already peripheral, the marginalization process produced different results, such as their further marginalization or a harddriven attempt to conform to Anglo norms to the detriment of national traditions. In France, however, the marginalization process encounters the national pride vested in a language often used for geopolitical and neo-colonial purposes, for example, through "Francophonie" discourses and institutions.

Aside from questions regarding linguistic ability, acknowledging this provincial status has been (and still is) problematic for many French geographers proudly attached to their national tradition and founding fathers (masculine intended, given the obstacles faced by, and the erasure of, women geographers). Feelings of insecurity and even resentment can be traced in many disciplinary discussions in France, with English-speaking geographies sometimes constituted as the other in relation to (or even against) whom some define themselves and their professional practices. An efficient tracer of this is the historically inaccurate, but politically and epistemologically significant, use of "Anglo-Saxon" to describe geographic literature in English, even when written by, say, Nigerian or Indian colleagues (Durand-Dastès, 2007). Hancock et al. (2019) have shown that "Anglo-Saxon", as many French geographers use it, is a floating signifier attached to whatever practice one wishes to either denounce or applaud and import. The disciplinary use of the term, to designate "the Other" of French geography (what we should do and do not, or should not do by all means, mirrors a similar use in the national discourses as Chabal has shown; Chabal, 2013). While this insularity might be receding, it has had consequences: French geography seems to be split first between colleagues that are more integrated into "international", English-speaking geographies and norms and those who remain rooted within French-speaking circles; second, between generations, as casualization increases, permanent jobs wane and publication requirements (including in English) for being recruited in tenured jobs reach unprecedented levels.

\subsection{Before we mourn excessively...}

While these feelings are certainly real, they should not overshadow the fact that this provincialization has happened to a very specific case. French geography was part and parcel of the national project and, as such, participated in the colonial project (Berdoulay, 2008 [1981]). We therefore do not refer to any province but to one that colonized a huge chunk of the world, imposed the French language on many coun- tries (this is basically about a previous linguistic hegemon whining about having become a linguistic commoner) and dominated geography (supplanting German-speaking models) for a good first half of the 20th century. During this time Vidalian geography was known worldwide, French geographers were experts in post-World War I border demarcation, and Emmanuel de Martonne, the physical geographer who was also Paul Vidal de la Blache's son-in-law and enforced disciplinary orthodoxy, ruled the International Geographical Union as secretary (1931-1938) and then president (19381949).

Consequently, it is crucial to expand the mostly descriptive use of the term provincial in Houssay-Holzschuch and Milhaud (2013) to a more theoretically informed and processual one enriched by the postcolonial analysis of Chakrabarty (1992). Such an expansion also allows us to go beyond French geographies and consider other European geographies. German-speaking geography was dominant during the 19th century as providing the discipline's theoretical framework and international recognized thinkers before Vidalians took over, and German has long been the main language of scientific discussion. Also, while not all European nations were as strong a colonial power, many were, and most benefited, if indirectly, from slavery and colonization. Their geographies were considered scientific and legitimate, their theories and concept universal, while others were dismissed, even erased. Most continental European geographies, unlike those of the UK, have been marginalized, some provincialized. Nevertheless, before we mourn our provincialization and peripheralization excessively, let us remember that they might be long overdue and a moral imperative.

\section{Ethical work in progress: repositioning continental European geographies}

I suggest that as continental European geographers, we should address our situation within global geographies as follows:

1. We fully acknowledge our provincial status.

2. We acknowledge that some of the pain and difficulties that we are experiencing might be linked to a problematic past - a past of power and privilege - to which we should not cling, and that some of our reactions might be akin to the white fragility in di Angelo $\left(2018^{4}\right)$.

\footnotetext{
${ }^{4}$ In a context of structural racism from which Whites benefit, Robin di Angelo defines white fragility as white people's inability to handle even very little racial stress, to the extent that it becomes intolerable and triggers defensive behaviors. In turn, these behaviors reinforce white domination. In our case, formerly dominant geographers whose position is losing ground are often triggered to exhibit defensive behaviors aimed at reinstating their previous position of prominence.
} 
3. We remember that a more just distribution of power can feel like (or even be) a loss of power for the privileged, which we still are.

4. And we start to do the hard work of repositioning ourselves more ethically.

This work of repositioning ourselves is not only about critical reflexivity but also about our choices of research themes, methods and theories; our relationship to "the local" and to the different places to which we belong; the ways we hold ourselves accountable; what and how we teach; etc. This work should be constant and perpetual, and the answers we provide will vary along the way, our career path and the local contexts. Of all possible angles, I next examine how the language in which we choose to write and the geographic localization of our fieldwork raise a series of important ethical questions when working from a province.

\subsection{Here and there}

As geographers, writing and fieldwork (under its many guises) are among our core research activities. When she engages in writing, a provincial Vidalians geographer needs to make a first decision: in what language should I be writing this particular piece? Although her answer will be embedded in various powers' worldwide relationships and be situated in terms of her country of origin, generation, precariousness, linguistic ability, etc., it will also reflect the choice of a specific audience, the one she wants to engage with through this particular text. I will untangle the stakes of three of her possible choices by locating her in France (see Curry and Lillis, 2014, 2017; Lillis and Curry, 2010, for a more global picture).

\subsubsection{Vivons heureux, vivons cachés? Writing in French}

Her first option is to write in French, which is her mother tongue, in which she can express herself smoothly, precisely and even beautifully. The ways of writing scientifically in French - the ternary structure, art of the allusion, and blending of empirical description and subtle references to theory - are familiar to her, having been socialized into them since high school and having internalized them. The choice of this language goes hand in hand with the choice of a set of concepts stemming from the Francophone tradition and French intellectual debates - she might just go for an approche territoriale. The questions she asks and answers in her research are in sync with French debates.

This choice is also one of accountability - if she works at a university, the French taxpayer pays her salary. If her work contributes to answering questions within French debates and is written in a language that her wider audience can read, it is legitimate. Moreover, the political economy of academic publishing in French is moving toward being increasingly open access (which the OpenEdition portal and the na- tional HAL online archive $^{5}$ offer), and the price that private publishers charge is a fraction of that of academic publishers of English academic texts. In other words, her work is rather accessible.

She can decide to locate her research in France or do fieldwork in another country. She could shed light on local issues or enrich French debates by bringing new insights from elsewhere - all locally relevant questions. Francophone audiences (of professional geographers and, crucially, beyond them) do have specific questions, concepts and debates, for which cases and concepts in different locations might offer answers. Such answers might not be attainable through secondary sources, as the research questions asked of these cases by researchers from other backgrounds are different. The geographer might even specialize in studying a specific country and become a national expert on a specific area. This geographical niche of expertise could advance her career at some point - a reward for her long commitment, for learning the area's language, gathering data, traveling, etc.

In short, there is definitely merit in a position of being accountable for local demands, being accessible, and contributing to the circulation of knowledge and ideas. But this position also risks reproducing existing neo-colonial relationships of power with the Global South if the research is undertaken there, as the Global South is used as a source of scientific material for the consumption of the French public. Moreover, it begs the question of what we do with the rest of the world - its existence in such a Franco-centric research conception, its theories, which differ from ours, and our place in it. Renaud Le Goix (2019) has recently demonstrated one of the possible pitfalls of this vivons heureux, vivons cachés position with the example of French urban research on North America. His work showed that 41 French or France-based colleagues have defended a $\mathrm{PhD}$ or an habilitation thesis on North American cities since 2009. One could expect that these (often brilliant) colleagues would act as a crucial interface between urban research in French and in English, and they indeed read and quote North American geographers, but it appears that their role as passeurs.euses goes only one way: Le Goix counted only 34 peer-reviewed publications in English written by these colleagues - namely less than a publication in English per person in 10 years. In other terms, research undertaken by French researchers, even when original and innovative, when quoting references written in English and dealing with empirical data mostly in English, does not share its findings with English-speaking audiences. Exchanges with other, less hegemonic, geographies have other kinds of sidedness, beyond not publishing in the languages read locally: are local geographers quoted, their concepts taken into account and conveyed to a French readership? Are their analyses used beyond the specific case to understand the French context? Isolationism thus remains the

\footnotetext{
5https://www.openedition.org (last access: 23 April 2020) and https://halshs.archives-ouvertes.fr (last access: 23 April 2020).
} 
risk of this first, possible, position, and it has to be addressed as such.

\subsubsection{Writing in English: France as a niche}

Owing to institutional and career pressures, or because she wants to engage with a wider audience, for example the global academic conversation, a provincial geographer might choose to write in English. This is not her first language, and the writing and publishing will take longer, be harder and be costlier. The Anglo publishing system is difficult to enter, and gatekeeping bars her way. If her research is located abroad, the local researchers will have longer and better access to the field. Consequently, she needs to find a niche, a specific angle from which she can make an original and innovative contribution. Her position allows her to use France as a niche.

On the one hand, this niche can be a theoretical one. French theory has been very successful, and she has the advantage of being able to read the original texts. She can also introduce new concepts, theories and authors by using her linguistic ability. However, translation, literal or conceptual, works best when introducing a text into one's own tradition. Anglo writers are therefore particularly apt to import concepts and theoretical points, as it is easier for them to successfully make them relevant to conceptual, themed or local debates in the Anglosphere.

On the other hand, the niche can be an empirical one. France can be used as a case that might shed light on a particular debate. This posture can be remarkably relevant, with the French case offering political geography insight into territorial dispositifs for nation-building, or for an iconic metropole that showcased modernity, or for a homogenizing answer to social and racial diversity. In turn, these cases can speak back to theory and have done so. If done well, this approach also requires an epistemological genealogy: how did France's major role in some phases of history, in the construction of what science should be during the Enlightenment and in the development of geographical thought shape a particular theory? In this case, working actively at provincialization requires excavating the epistemological past and demarcating its influence on theory. The approach also signals an end to the too frequent use of France as an implicit frame of reference in French geographical research and teaching. Although France as an empirical niche can be a very fruitful individual position, not all French geographers can occupy it: not only do not all French geographers want to work on the French case (why would they, and why would a case be the locals' preserve, as long as ethical rules of engagement are respected?), but such limitations would be isolationist (therefore ethically problematic) as well as politically and scientifically counterproductive.

\subsubsection{In-betweenness as praxis}

A last choice is to practice in-betweenness between academic worlds and between different worlds of everyday, embodied experiences (Nagar, 2019), such as fieldwork or teaching. Inbetweenness is a real praxis, as it needs constant reflexivity; a rigorous theoretical inquiry; and a continual adaptation to situations, configurations and the choices at hand as well as political awareness of what is at stake. The researcher is never at rest in a posture but in a constant flux of adaptation to and choices regarding an audience, a language, and a theory or research question, all of which need to be rethought before each research or writing project. While this is (should be!) true of each research situation, in-betweenness requires a heightened and acute awareness of all these choices. Whom do I want to address? What issues do I want to raise - are they local or global ones, and why, as Maha Bali (2018) pointed out, should some have more value than others? Should not we intensify our efforts to experiment in European settings with theories produced elsewhere?

However, embracing in-betweenness requires an awareness of how the physical distance from one's field and the differences between languages constitute not only practical but also ethical challenges, namely disjointed accountabilities. The in-between scholar is accountable to several disjointed communities: the one that (co-)produces her data or where the data is collected, the academic community of the country where she does her fieldwork, her national academic community, the global academic community, and the general public in the country where she lives and works. These communities differ regarding their location, languages, journals of reference, theoretical frameworks, access to academic literature, etc. In such a situation, the in-between scholar's accountability work is increased exponentially. Furthermore, the material requirements of accountability are always at risk, as she is always exposed to funding cuts, which could prevent her returning to her field for the restitution of her research to the local community. Consequently, satisfying levels of accountability are incredibly hard to attain. For merely acceptable levels of accountability, the challenges raised by distance and disjunction need to be incorporated into the methods and research question from the very beginning to avoid (or at least minimize) extractive and predatory research. A lengthy commitment to a specific site (Jazeel, 2019) is especially precious here - in other words, a long-distance relationship should also be long-term.

The in-between research posture is therefore highly fluid, even risky, due to its always endangered ethical engagement (Nagar, 2019). Whatever the case, all three options - inwardlooking, the niche and in-betweenness - have some legitimacy and all require reflexivity. None is unproblematic. They need to be carefully and always critically nurtured and refined: all of them try to foster a positive and reflexive relationship with the rest of the world, together with a critical awareness of the researcher's positionality within it - a posi- 
tioning that can be modeled for our students and, by extension, for the general public. For instance, our pedagogies and reading lists can be much more explicit on our positionality and how we engage with the rest of the world: presenting geographers from other provinces in our History of Geography undergrad course, positioning the geography of our respective country not as interesting in and for itself but as a case, through comparisons and an explicit epistemology of what that case brings to the discussion. In other terms, this means never shutting the world out of our classrooms and public interventions. This is crucial and our responsibility to prevent continental Europe from isolating itself in wealth and racism to the extent that Greek border patrols fire at asylum seekers as I revise this piece ${ }^{6}$, especially as forms of neo-fascism and authoritarianism are on the rise worldwide and on the continent (see Wodak, 2019, for a recent overview; and Loher and Strasser, 2019, for the consequences this has on the academy).

\subsection{Repositioning while contributing to a more cosmopolitan geography}

The way we deal with our provincialism and how we actively embrace provincialization should not happen in isolation from the international discussion on building a more cosmopolitan geography and efforts to do so (Robinson, 2003). Southern Theory (Connell, 2007; Comaroff and Comaroff, 2011) has shown us how to work from a different perspective, using other theorists and fashioning new concepts. In a symmetrical fashion, our repositioning has to include reevaluating our relationship not only to other geographies but also to the "local". Dumping local perspectives and needs should certainly not be the prize of participating in the debates of the international community of geographers. Local engagement and its diverse forms, depending on our fields of expertise, benefit from international discussions and from a careful work of trans-lation, dis-location and relocation that provincial geographers are well-placed to engage in. The most obvious and immediate area in which to engage in this work is our teaching. Moreover, to move beyond the persistent coloniality of knowledge production (Mignolo, 2007) that is, to undertake decolonial work (Dijkema and Babar, 2019; Jazeel, 2017) - we need to constantly ponder (and act on) the pointed questions in Maha Bali (2018):

- "Who has the privilege to choose to have global or local perspectives?"

- "Who bears responsibility to make the effort for global perspectives to be heard?"

\footnotetext{
${ }^{6}$ Sadiq Maheen (2020), "Greek coastguards in altercation with migrant dinghy as Turkey opens border", The Guardian, March 2, https://www.theguardian.com/world/video/2020/mar/02/greekcoastguards-altercation-migrant-dinghy-turkey-opens, last access: 10 March 2020.
}

- "Whose fault is it that global perspectives are not heard?"

As continental European geographers, our answers are to recognize that we largely retain the privilege of choosing our perspectives. Although case studies from continental Europe no longer carry the weight they used to, theories that appear to be legitimately global tend to stem from the West, be they inherited from the Enlightenment or French and emerging Italian theory (Minca, 2016). This is our privilege, and, especially in our teaching perhaps, we retain much latitude to have our local perspectives masquerade as global or universal. With regard to our responsibility for having global perspectives heard, we must remember that while decolonial work is mostly in the hands of and, crucially, led by marginalized people - whether they belong to institutions of the Global South or to minoritized groups in our institutions, it does not mean that we do not have work to do, quite the opposite. In this regard, our work is to make space for and try to refrain from appropriating or profiting from decidedly plural global perspectives - e.g., by using marginalized people's intellectual labor to further our personal careers, even if there is no silver bullet that would ensure this. Lastly, we should ask ourselves whether global and diverse perspectives are heard within Francophone (Germanophone, etc.) geographies. How many women do we listen to, and how many racialized geographers (whether Francophone or French) do we publish in this still very white discipline (Noxolo, 2017)? And while "very few" is the painfully obvious answer, what do we do to support and nurture marginalized students; to shepherd their papers for publications as teachers, supervisors and editors (Springer et al., 2017); or to support their job applications and promotions?

\section{Immediate practical steps}

Such grand calls for more cosmopolitan and decolonized geographies need to include immediate practical steps for action (Robinson, 2003). In this regard, I identify multilingualism, citation politics and publication ethics as immediate avenues for action.

\subsection{Multilingualism}

Multilingualism is part and parcel of the provincial condition. While having to express oneself in a language that is not one's own has been lamented, and one's written research is often assessed and derided by the English-speaking sphere as "lacking" (in linguistic ability, theoretical interest, etc.), such linguistic acrobatics have also sparked great creativity - from the very practical to the highly conceptual. Mary Jane Curry and Theresa M. Lillis (2014) have highlighted the diverse tactics and strategies that European scholars from Spain, Portugal, Hungary and Slovakia deploy to publish from their provincial or peripheral positions. Beyond pragmatic tac- 
tics to circumvent gatekeeping, continental European geographers should embrace multilingualism far more. There is, however, an ethical caveat: our multilingualism is often between colonial languages (e.g., French, English, Spanish and German), whose history has allowed them to become international languages. This kind of multilingualism is significantly different from that of formerly colonized geographers, whose multilingualism combines colonial language(s) and at least one devalorized "vernacular" that has never been recognized as a legitimate scientific language.

Multilingualism should be fostered within articles by quoting from and engaging with literature in several languages. This practice is becoming more common as continental European geographers engage more consciously with the "niche" posture, which the Anglosphere is increasingly accepting. For example, Progress in Human Geography, a highly recognized journal, now includes the following sentence in its request for review work: "In order to try to encourage submissions from beyond the anglophone world, the editors of PiHG would be particularly grateful if you could indicate whether the range of references cited in this paper is representative of the best of work in its field from around the world". Multilingualism should also go beyond the English or mother tongue binary to include other European languages and beyond, the languages of the places we do fieldwork, etc. (Phipps, 2019).

A last crucial element in practising multilingualism for provincialization refers to the politics of translation (Husseini de Araújo and Germès, 2016; Hancock, 2016). "What might it take to reimagine translation as a dynamic, multidirectional process of ethical and politically aware mediation among otherwise impermeable local diversities - a process that always hungers for new political possibilities that we may never have imagined before?", asks Richa Nagar (2019). While several European countries have actively developed translation policies, others lag behind; tellingly, David Harvey's Paris capital of modernity was only translated into French(!) in 2012 by a group of young geographers volunteering their free labor under the leadership of the late Matthieu Giroud (Harvey, 2012). We need to translate more and to translate from more diverse languages. German- or Spanish-speaking geographies, for instance, are rarely accessible in other languages, and our proficiency in other languages is limited. We also need to recognize that translation has a cost, monetary or timewise, that needs to be taken into account. In addition, examining translation seriously (Crane et al., 2009) requires reflexivity regarding our diverse ways of writing scientifically, reflexivity fostered by actual practices of writing in different languages. What do we have to change in our ways of writing when we switch languages? How does our relationship to literature, to empirical data and to concepts evolve? Translation is also a conceptual horizon, with concepts resisting it (Cassin, 2004) and interlinguistic friction being a prime indicator of new theoretical explorations. As the researcher navigates different languages' theories and concepts, she can benefit from what Heinz Wissmann called the Babel effect, allowing herself be guided in her research exploration by "les champs de force que les langues créent entre elles, avec des problèmes qui naissent de leurs différences et parfois de leurs convergences [the force fields that languages create between one another, producing problems as they differ and sometimes converge]" (Wismann, 2012).

\subsection{Citation politics}

Sarah Ahmed (2017) has brilliantly drawn our attention to the importance of citation politics and to the way current citation practices work to maintain a certain political and scientific order. Whom we cite matters. @ MarikaRose (2017) has skillfully listed why "referencing is political." I quote her at length here:

- "Citations are academic currency: it has value, it ascribes value.

- Referencing is about accountability: it lets others go and check your work.

- Referencing is about payment: it acknowledges what you owe, to whom.

- Citation is about gatekeeping: it recognizes some kinds of texts and ideas as more valuable than others (...).

- It is not just how you cite, it is who you cite. Which thinkers do you value? What kind of authority do you recognize?"

Implementing these principles within our embraced provincialization could entail many different actions, such as diversifying our reference list beyond our national and usual Anglo suspects to include more marginalized geographers. While there are many causes of marginalization, our European positionality, steeped in whiteness and a Western regime of scientific legitimacy, should specifically include Southern, black and indigenous colleagues as well as nonacademic scholars. In this specific setting, referencing as payment could be interestingly reframed as referencing as reparations and an acknowledgement of invisibilized debts. Our own gatekeeping practices by means of citation should also be questioned, especially in provincial settings. Who is listed as a reference in our articles' bibliographies or in those we give our students? Do we quote the colleagues that our provincial organization regards as neo-colonial dependents, and do we quote them for their theoretical input or merely for their empirical data, thus reproducing the Anglosphere gatekeeping practices that we dislike? Whose authority do we actually recognize as an authority and not as a legitimation process for our own benefit?

\subsection{Publication ethics}

Lastly, provincialization can benefit from a critical look at publication ethics. Our journals should also welcome papers 
in different languages - some already do. Making translations accessible on journal websites when authors can provide these is also very valuable. For example, the "Fuck neoliberalism" paper by Simon Springer (2016) published in $A C M E$ is available in 16 different languages. Real open access, which is much stronger in French- and Spanishspeaking geographies than in others, should be encouraged, although Piron et al. (2017; as translated in Nobes, 2017) also warn us about the "neo-colonial face of open access":

if open access is to facilitate and accelerate the access of scientists from the South to Northern science without looking into the visibility of knowledge of the South, it helps to redouble their alienation epistemic without contributing to their emancipation. Indeed, by making the work of the center of the world-system of science even more accessible, open access maximizes their impact on the periphery and reinforces their use as a theoretical reference or as a normative model, to the detriment of local epistemologies.

Indeed, many open-access journals struggle with receiving submissions from Southern scholars, and those that arrive tend to come from emerging countries, especially, and understandably, if the journal has a good ranking. Piron et al. (2017; as translated in Nobes, 2017) therefore call for "decentralized, decolonized" open access that "must include the concern for origin, creation, local publishing and the desire to ensure equity between the accessibility of the publications of the center of the world system and that of knowledge from the periphery". Building such a system is a responsibility we should share.

\section{Conclusion}

This paper aims at making a case for embracing rather than lamenting continental European geographies' provincialization as the ethical thing to do. Drawing from a Frenchcentered view of Francophone geographies and from an analysis of their contemporary situation, the paper highlights their marginalization, insularity and provincialism. Although critical geographies of knowledge production have focused on the well-known opposition between the Anglosphere and other geographies, they have tended to bypass a discussion on what is at stake within a very diverse periphery.

I suggest that within this still actively produced periphery, continental European geographies, which are themselves diverse and diversely positioned, face a specific challenge that should be understood as an ethical one. Certain European geographies (usually French or German) were developed within colonial states and, at some point, ruled the discipline globally. Being provincialized should not only be experienced as a loss of power - which it certainly is, namely the loss that goes with the end of hegemony - but should also be welcomed because it opens up many possibilities for more truly cosmopolitan geographical practices. Such practices acknowledge their colonial past and contribute from that position to more cosmopolitan geographies. Actions to this end differ according to our location: some colleagues in the UK or in English-speaking North America have started this work by characterizing their situation and setting a plan of action (see for instance Noxolo, 2017; de Leeuw and Hunt, 2018). There is also hard work ahead for us in continental Europe in terms of repositioning and provincializing ourselves. I endeavored to delineate some of our dilemmas and options when choosing a language for writing or a fieldwork site and how these choices raise issues of audience, accountability, access and power. The options are legitimate, but they are also problematic, requiring constant reflexivity and adjustment in order to be more ethical. I subsequently proposed potential practical steps regarding multilingualism, citation politics and publications ethics. I know that this is a tall order, and we are bound to fail. But we shall try again.

Data availability. No data sets were used in this article.

Competing interests. The authors declare that they have no conflict of interest.

Acknowledgements. This paper stems from countless discussions over the years, and I am very grateful to all the people who helped me shape my thinking. Thanks in particular to the reviewers for their constructive input; to Estelle Sohier and Benedikt Korf, who invited me to present seminars at, respectively, the University of Geneva and Zurich; to Virginie Mamadouh for our discussions; to Jenny Robinson, whose work has constantly inspired me; to Claske Dijkema, who pushed me gently and firmly into the decolonial; and to the \#Menthonnex academic writing crew and its co-head conspirator Renaud Le Goix for a writing h(e)aven. Lastly, thanks to Ilse Evertse, Kirsten Koop, Cristina Del Biaggio and Alberto Campi, who ensured that my attempts at multilingualism were grammatically correct and somehow legible, and to PACTE for funding this. The remaining faults are my responsibility.

Review statement. This paper was edited by Benedikt Korf and reviewed by two anonymous referees.

\section{References}

Aalbers, M. B. and Rossi, U.: A coming community: young geographers coping with multi-tier spaces of academic publishing across Europe, Social Cult. Geogr., 8, 283-302, 2007.

Ahmed, S.: Living a Feminist Life, Duke University Press Books, Durham, 2017. 
@MARIKAROSE: Referencing is political, available at: https: //twitter.com/marikarose/status/934014883259207680 (last access: 24 November 2019), 2017.

Bajerski, A.: The role of French, German and Spanish journals in scientific communication in international geography, Area, 43, 305-313, https://doi.org/10.1111/j.1475-4762.2010.00989.x, 2011.

Bali, M.: The Privilege to Choose Global Perspectives. Reflecting Allowed, available at: https://blog.mahabali.me/writing/ the-privilege-to-choose-global-perspectives, last access: 31 October 2018.

Berdoulay, V.: La formation de l'école française de géographie (1870-1914), 3ème édition avec un nouveau postscript 2008, Éditions du CTHS, Paris, 2008, 246-259, [1981].

Cassin, B.: Vocabulaire européen des philosophies : dictionnaire des intraduisibles, Le Robert: Seuil, Paris, xxiv, 1531 pp., 2004.

Chabal, E.: The Rise of the Anglo-Saxon: French Perceptions of the Anglo-American World in the Long Twentieth Century, French Polit. Cult. Soc., 31, 24-46, 2013.

Chakrabarty, D.: Postcoloniality and the Artifice of History: Who Speaks for "Indian" Pasts?, Representations, in: Special Issue: Imperial Fantasies and Postcolonial Histories, 1-26, 1992.

Comaroff, J. and Comaroff, J. L.: Theory from the south, or, How Euro-America is evolving toward Africa, Paradigm Publishers, Boulder, CO, 2011.

Connell, R.: Southern Theory. The Gobal Dynamics of Knowledge in Social Science, Polity, Cambridge, 2007.

Crane, L. G., Lombard, M. B., and Tenz, E. M.: More than just translation: challenges and opportunities in translingual research, Social Geogr., 4, 39-46, https://doi.org/10.5194/sg-4-39-2009, 2009.

Curry, M. J. and Lillis, T. M.: A Scholar's Guide to Getting Published in English, in: Critical Choices and Practical Strategies, Multilingual Matters, Bristol, 2013.

Curry, M. J. and Lillis, T. M.: Strategies and tactics in academic knowledge production by multilingual scholars, Educ. Policy Anal. Arch., 22, 1-24, https://doi.org/10.14507/epaa.v22n32.2014, 2014.

Curry, M. J. and Lillis, T.: Problematizing English as the Privileged Language of Global Academic Publishing, in: Global Academic Publishing: Policies, Perspectives and Pedagogies, edited by: Curry, M. J. and Lillis, T., Multilingual Matters, Clevedon, 1-20, 2017.

de Leeuw, S. and Hunt, S.: Unsettling decolonizing geographies, Geogr. Compass, 12, e12376, https://doi.org/10.1111/gec3.12376, 2018.

di Angelo, R.: White Fragility: Why It's So Hard for White People to Talk About Racism, Beacon Press, Boston, 2018.

Dijkema, C. and Babar, K. A.: Ville et Pensée décoloniale, in: Pour une géopolitique critique du savoir, Cahier des 3èmes Rencontres de Géopolitique critique, MODOP, Grenoble, 2019.

Durand-Dastès, F.: Un envahisseur linguistique: l'AngloSaxon, Cybergeo: Eur. J. Geogr., available at: http: //journals.openedition.org/cybergeo/11933 (last access: 24 April 2020), 2007.

Garcia-Ramon, M.-D.: Globalization and international geography: the questions of languages and scholarly traditions, Prog. Human Geogr., 27, 1-5, https://doi.org/10.1191/0309132503ph409xx, 2003.
Graham, M., Hale, S. A., and Stephens, M.: Geographies of the World's Knowledge, edited by: Flick, C. M., Convoco! Edition, London, 2011.

Hancock, C.: Traduttore Traditore, The Translator As Traitor, ACME: Int. J. Crit. Geogr., 15, 15-35, 2016.

Hancock, C., Mahoudeau, A., and Houssay-Holzschuch, M.: Pour en finir avec "Anglo-saxon": lever un frein aux approches critiques en géographie, Approches critiques de la dimension spatiale des rapports sociaux: débats transdisciplinaires et transnationaux, Caen, 26-28 Juin 2019.

Harvey, D.: Paris, capitale de la modernité, Les Prairies ordinaires, Paris, 2012.

Houssay-Holzschuch, M. and Milhaud, O.: Geography after Babel - a view from the French province, Geogr. Helv., 68, 51-55, https://doi.org/10.5194/gh-68-51-2013, 2013.

Husseini de Araújo, S. and Germès, M.: For A Critical Practice of Translation in Geography, ACME: Int. J. Crit. Geogr., 15, 1-14, 2016.

Imhof, N. and Müller, M.: How international are geography journals? Not international enough, Environ. Plan. A, https://doi.org/10.1177/0308518x20907608, in press, 2020.

Isopahkala-Bouret, U., Börjesson, M., Beach, D., Haltia, N., Jónasson, J. T., Jauhiainen, A., Jauhiainen, A., Kosunen, S., Nori, H., and Vabø, A.: Access and stratification in Nordic higher education. A review of cross-cutting research themes and issues, Educ. Inquiry, 9, 142-154, https://doi.org/10.1080/20004508.2018.1429769, 2018.

Jazeel, T.: Mainstreaming geography's decolonial imperative, T. Inst. Brit. Geogr., 42, 334-337, https://doi.org/10.1111/tran.12200, 2017.

Jazeel, T.: Singularity. A manifesto for incomparable geographies, Singapore J. Trop. Geogr., 40, 5-21, https://doi.org/10.1111/sjtg.12265, 2019.

Knafou, R.: L'état de la géographie: autoscopie d'une science, Paris, Belin, 1997.

Korf, B., Klauser, F., and Söderström, O.: Editorial: Les fabriques des "géographies" - making academic geographies in Europe, Geogr. Helv., 68, 1-6, https://doi.org/10.5194/gh-68-12013, 2013.

Le Goix, R.: Un état des lieux de la géographie urbaine française en Amérique du Nord (2009-2019), Congrès de 1'Institut des Amériques, Aubervilliers, October 2019.

Lillis, T. and Curry, M. J.: Academic Writing in a Global Context. The Politics and Practices of publishing in English, Routledge, London, 2010.

Loher, D. and Strasser, S.: Politics of precarity: neoliberal academia under austerity measures and authoritarian threat, Social Anthropol., 27, 5-14, https://doi.org/10.1111/1469-8676.12697, 2019.

Mamadouh, V.: Do you speak Globish? Geographies of the globalization of English and linguistic diversity, in: Handbook on the Geographies of Globalization, edited by: Kloosterman, R. C., Mamadouh, V., and Terhorst, P., Edward Elgar Publishing, Cheltenham, 209-221, 2018.

Mignolo, W. D. G. E.: Special issue: Globalization and the DeColonial Option, Cult. Stud., 21, 2007.

Minca, C.: Venetian geographical praxis, Environ. Plan. D, 18, 285 $289,2000$. 
Minca, C.: Italian Studies, Italian Theory and the politics of trans-lation, Environ. Plan. D, 34, 822-829, https://doi.org/10.1177/0263775816656526, 2016.

Nagar, R.: Hungry Translations: The World Through Radical Vulnerability, Antipode, 51, 3-24, https://doi.org/10.1111/anti.12399, 2019.

Nobes, A.: Must we decolonise Open Access? Perspectives from Francophone Africa, journalologik, available at: http:// journalologik.uk/?p=149 (last access: 8 December 2018), 2017.

Noxolo, P.: Introduction: Decolonising geographical knowledge in a colonised and re-colonising postcolonial world, Area, 49, $317-$ 319, https://doi.org/10.1111/area.12370, 2017.

Phipps, A.: Decolonising Multilingualism. Struggles to Decreate, in: Writing Without Borders, Multilingual Matters, NB, 2019.

Piron, F., Diouf, A. B., Dibounje Madiba, M. S., Mboa Nkoudou, T. H., Ouangré, Z. A., Tessy, D. R., Achaffert, H. R., Pierre, A., and Lire, Z.: Le libre accès vu d'Afrique francophone subsaharienne, Revue française des sciences de l'information et de la communication, 11, https://doi.org/10.4000/rfsic.3292, 2017.
Robinson, J.: Postcolonialising Geography: Tactics and Pitfalls, Singapore J. Trop. Geogr., 24, 273-289, https://doi.org/10.1111/1467-9493.00159, 2003.

Springer, S.: Fuck Neoliberalism, ACME: Int. J. Crit. Geogr., 15, 285-292, 2016.

Springer, S., Houssay-Holzschuch, M., Villegas, C., and Gahman, L.: Say 'Yes!' to peer review: Open Access publishing and the need for mutual aid in academia, Fennia, 195, 185-188, https://doi.org/10.11143/fennia.66862, 2017.

Van Parijs, P.: Choisir l'anglais, c'est choisir l'exclusion minimale, Le Monde, 2004.

Wismann, H.: Penser entre les langues, Bibliothèque Idées, Albin Michel, Paris, 2012.

Wodak, R.: Entering the 'post-shame era': the rise of illiberal democracy, populism and neoauthoritarianism in EUrope, Global Discourse, 9, 195-213, https://doi.org/10.1332/204378919X15470487645420, 2019. 